\title{
Aktuální témata kardiovaskulární prevence
}

Nad otázkami „Proč Češi tráví v nemoci neúměrně mnoho let? Co za tím stojí a jak změnit tento negativní trend?“ diskutovali během 29. výročního sjezdu České kardiologické společnosti prof. MUDr. Aleš Linhart, DrSc., FESC, FCMA, a prof. MUDr. Jan Pitha, CSc. Přinášíme v hlavních bodech obsah jejich diskuze.

I pres pokroky medicíny v oblasti kardiovaskulárního (KV) zdraví tráví Češi mnoho let svého života s KV onemocněním. Českým ženám patřilo v roce 2016 z hlediska tohoto parametru druhé nejhorší místo v Evropě, českým mužưm 6. nejhorší místo (Obr. 1) (1). Při střední délce života 81,9 roku tráví české ženy 20 let svého života s KV onemocněním, u mužů při střední délce života 76,1 roku představuje čas strávený s onemocněním 15 let. Spolu se stárnutím populace znamená tento fakt obrovské ekonomické náklady, zátěž pro zdravotní systém a snižení kvality života pacientů. Pojd’me se na ilustračním př́kladu pacienta zamyslet nad tím, proč je stav české populace z tohoto pohledu tak nepřiznivý a jak lze tuto situaci změnit.

\section{Jak by měl vypadat ideální zdravotní stav z hlediska kardiovaskulárního rizika?}

Jako modelového pacienta pro ilustraci časného a dlouhodobého zvýšení KV rizika jsme zvolili 38letého muže. Jde o typického jedince dnešní doby se sedavým způsobem života, který každý den vypije průměrně 2 piva a vykouři 20 cigaret. Jeho BMI je $32,5 \mathrm{~kg} / \mathrm{m}^{2}$, krevní tlak 156/96 mm Hg, hladina LDL cholesterolu (LDL-C) 3,8 mmol/l, kyseliny močové 496 $\mu \mathrm{mol} / \mathrm{I}$ a gamaglutamyltransferázy (GGT) 2,8 $\mu$ kat/l.

Ideální situace by u tohoto muže znamenala: nekuřáctví, 30 minut přiměřené pohybové aktivity denně, BMI $<25 \mathrm{~kg} / \mathrm{m}^{2}$, obvod pasu $<102$ cm (u žen < 88 cm), krevní tlak 130-140/80-90 mm Hg, glykemie nalačno $<5,6 \mathrm{mmol} / \mathrm{I}$ a hladina LDL-C $<1,4 \mathrm{mmol} / \mathrm{l}$.

Opatření v době pandemie covidu-19 s sebou přinesla omezení pohybové aktivity a zvýšení tělesné hmotnosti u velké části populace spolu s vynecháváním preventivních prohlídek. Jedinců s ideálním profilem KV zdraví proto budeme nyní vídat méně a je třeba se pripravit na nárůst počtu pacientů se zvýšeným KV rizikem.

\section{Je u mladého pacienta na místě léčba hypertenze?}

U popsaného pacienta jistě vyvstává otázka kompenzace krevního tlaku (TK). Metaanalýza 123 studií léčby hypertenze, které proběhly v letech 1966-2015 a zařadily 613815 účastníků, prokázala významný pokles rizika výskytu velkých KV príhod, který odpovídá 20\% snižení při poklesu TK o 10 mm Hg. Toto snížení TK bylo také spojeno s poklesem rizika vzniku ischemické choroby srdeční (ICHS), cévních mozkových príhod (CMP), srdečního selhání a celkové mortality (2). Proto je kompenzace hypertenze na místě již u našeho 38letého nemocného. Motivovat ho k léčbě hypertenze bude ale jistě nelehký úkol.

Je důležité si uvědomit, že snížení TK u osob s hypertenzí je spojeno se zachováním cévního zdraví. Vysoký krevní tlak nepř́iznivě působí na cévy po celou dobu svého trvání. Při výskytu hypertenze v mladším věku jsou cévy vystaveny mnohaletému nepríznivému vlivu vysokého krevního tlaku. Z tohoto pohledu jsou zajímavé výsledky projektu využívajícího data z UK Biobank (3) od 438952 účastníků, kteří byli stratifikováni podle př́tomnosti exomových variant spojených s hladinou LDL-C a s hodnotou systolického krevního tlaku (STK). Účastníci ve věku 40-80 let byli sledováni od roku 2006-2010 do roku 2018. Rozděleni byli do 4 skupin: s geneticky daným vysokým LDL-C (průměr 3,74 mmol/l) i TK (průměr 139,2 mm Hg), s geneticky daným vysokým LDL-C (průměr 3,78 mmol/l) a nízkým TK (průměr 136,3mm Hg), s geneticky daným vysokým TK (průměr 139,2mm Hg) a nízkým LDL-C (průměr 3,36 mmol/l) a s genetickou predispozicí k nízkému LDL-C (průměr 3,38 mmol/l) i TK (průměr 136,2 mm Hg). Ačkoliv rozdíly mezi hodnotami jednotlivých parametrů se zdají malé, dlouhodobá expozice nižšímu TK a nižší hladině LDL-C byla v porovnání se skupinou s geneticky danými vysokými hodnotami TK a LDL-C spojena s významným snížením rizika KV príhod o 39 \%. Významné snížení KV rizika bylo pozorováno i u skupiny, která měla geneticky daný pouze nízký LDL-C (o 27 \%), a také u skupiny, která měla geneticky daný pouze nízký STK (o 18\%). Snižení KV rizika spojené s celoživotně nižší hodnotou TK o 10 mm Hg a LDL-C o 1 mmol// ukazuje Obr. 2: nižší TK znamená snižení KV rizika o 49 \%, nižší LDL-C o 57 \% a nižší TK i LDL-C o 78 \% (3). Časnou kompenzací hypertenze u mladých pacientů tedy zabráníme mnohaletému nepríznivému působení tohoto KV rizikového faktoru.

\section{Jak moc razantnĕ je třeba TK snižovat?}

Optimální hodnoty STK se pohybují mezi 120 a 140 mm Hg. Křivka závislosti KV rizika na hodnotě STK má tvar písmene U (4). Znamená to, že vyšší, ale i nižší hodnoty STK jsou spojeny s vyšším KV rizikem (KV mortalita, výskyt CMP, infarktu myokardu [IM], hospitalizace pro srdeční selhání). Víme tedy, že by krevní tlak neměl být snižován př́liš razantně. Je ovšem třeba si uvědomit, že výsledky byly získány u populací pacientů obvykle starších 50 let, tedy nikoliv u mladších nemocných odpovídajících věkem našemu modelovému pacientovi. Observační 
Obr. 1. Roky strávenév nemoci z důvodu KV onemocnění (přepočteno na milion). Upraveno dle GBD 2017 Disease and Injury Incidence and Prevalence Collaborators (1)

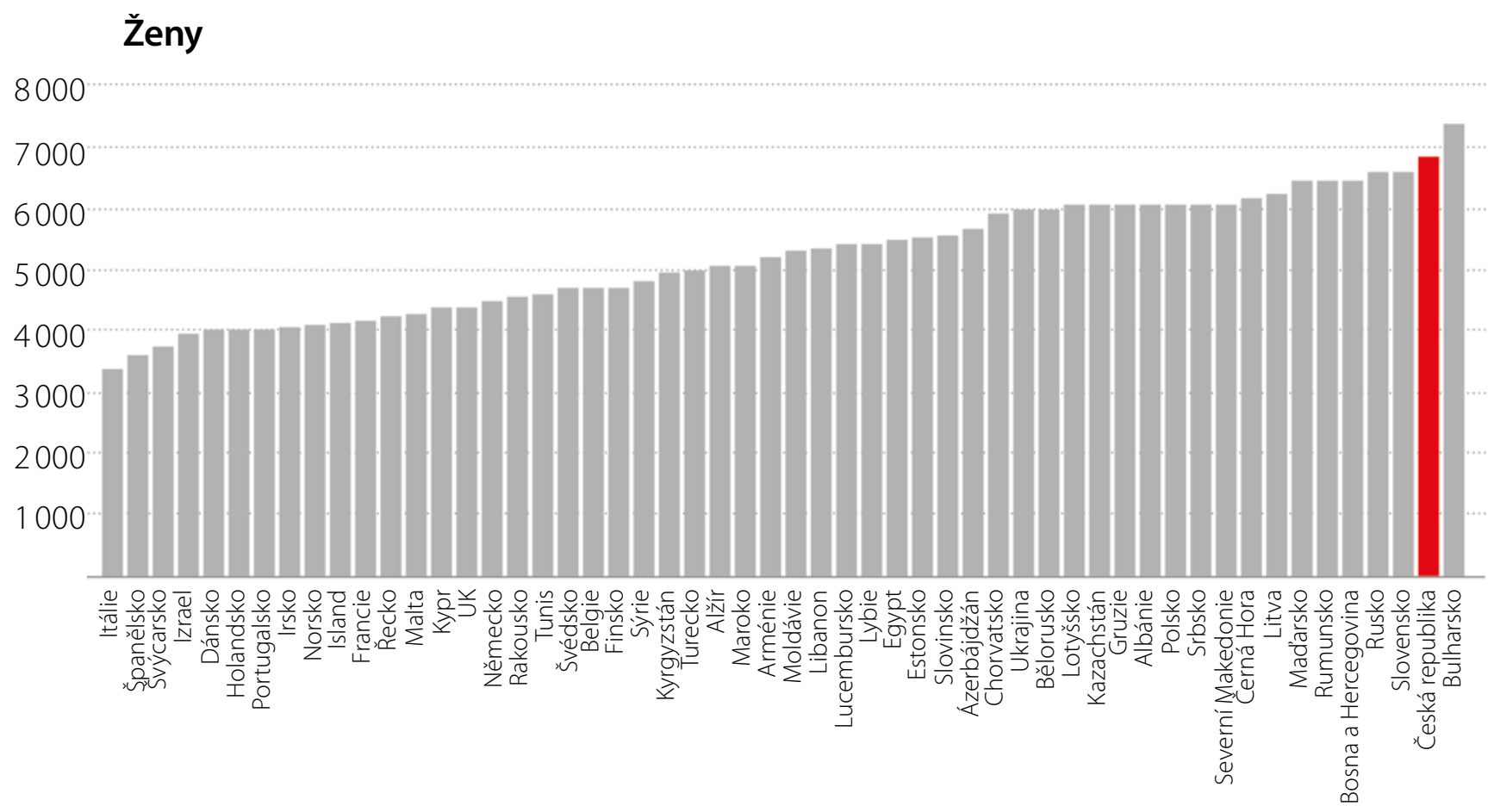

\section{Muži}

10000

8000

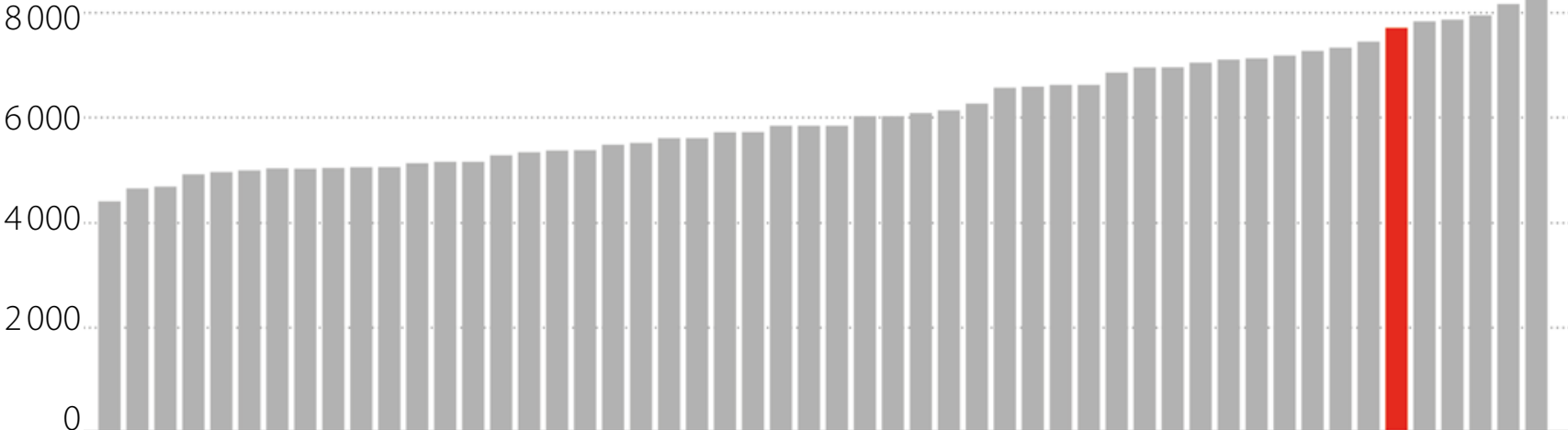

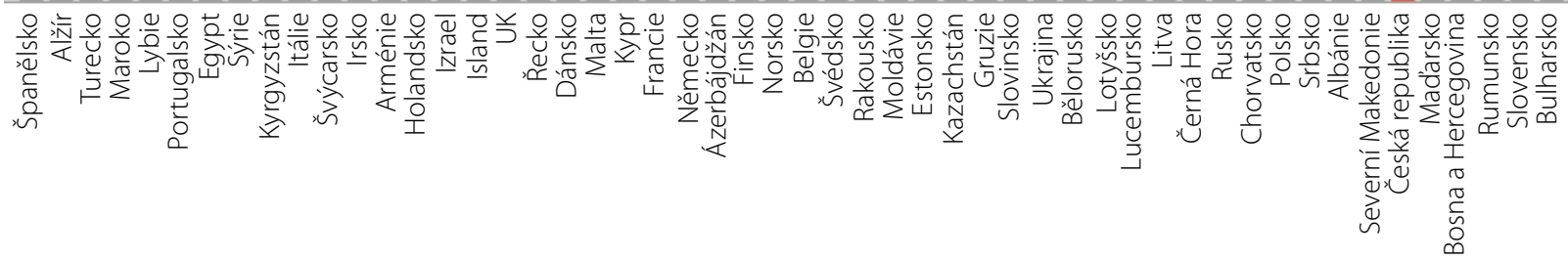

studie, která hodnotila dopad kompenzace 5 KV rizikových faktorů u pacientů s diabetem 2. typu (glykemie, LDL-C, TK, kouření, albuminurie) na výskyt KV př́hod, ukázala o 45 \% vyšší riziko hospitalizace u pacientů, kteří neměli kompenzovaný žádný z těchto KV rizikových faktorů, ovšem v podskupině do 55 let věku bylo riziko hospitalizace vyšší 11 násobně (5). Kompenzace TK a dalších KV rizikových faktorů již u pacientů mladšího věku by tedy mohla vést i ke snížení zátěže zdravotního systému. Nezapomínejme, že hypertenze je nejvýznamnějším rizikovým faktorem KV mortality a 5. nejvýznamnějším rizikovým faktorem celkové mortality (6).

\section{Je vhodné u mladšího pacienta s hypertenzí hodnotit změny cílových orgánů?}

Hypertenze má samozřejmě nepříznivý dopad na strukturu stěny cév a myokardu. Stav cílových orgánů hypertenze je možné využít k motivaci pacientů. Aterosklerotické změny nelze podceňovat ani v mladším věku. Studie, která hodnotila stav koronárních tepen 262 zdravých kadavernózních dárců orgánů, ukázala výskyt aterosklerotických plátů u 17 \% jedinců do 20 let, 37 \% jedinců ve věku 20-29 let, 60 \% jedinců ve věku 30-39 let, 71 \% jedinců ve věku 40-49 let a 85 \% jedinců starších 50 let (7). 


\begin{tabular}{|c|}
\hline Hlav \\
\hline Češi tráví průměrně \\
\hline $\begin{array}{l}\text { Vzhledem } \mathrm{k} \text { opatřením během pandemie covidu-19 je třeba se } \\
\text { připravit na nárůst počtu pacientů se zvýšeným KV rizikem. }\end{array}$ \\
\hline $\begin{array}{l}\text { Kompenzace hypertenze je na místě i u mladších pacientů, u nichž } \\
\text { Ize využít mnohaleté príznivé působení nízkého krevního tlaku } \\
\text { (STK } 120-140 \mathrm{~mm} \mathrm{Hg} \text { ) na zdraví cév. }\end{array}$ \\
\hline $\begin{array}{l}\text { U mladších pacientů s dyslipidemií je třeba využít i dlouhodobého } \\
\text { prínosu snížení hladiny LDL-C. }\end{array}$ \\
\hline $\begin{array}{l}\text { Ultrasonografické zobrazení aterosklerotického plátu va. carotis nebo } \\
\text { zjištěnou zvýšenou tuhost cév dle PWV je možné využít k motivaci } \\
\text { pacienta k léčbě. }\end{array}$ \\
\hline $\begin{array}{l}\text { Ignorování primární KV prevence vede u jedinců s hypertenzí } \\
\text { a dyslipidemií } k \text { poškození cílových orgánů a důsledkem je časný } \\
\text { výskyt aterosklerotických příhod ještě v produktivním věku a značná } \\
\text { část života strávená v nemoci. }\end{array}$ \\
\hline $\begin{array}{l}\text { Cílem sekundární KV prevence je snížení rizika výskytu dalších } \\
\text { aterosklerotických príhod důslednou kompenzací rizikových faktorů. }\end{array}$ \\
\hline $\begin{array}{l}\text { Pro dosažení účinku léčby je rozhodující adherence. Pro její zvýšení je } \\
\text { třeba volit léčbu s ohledem na lékové interakce, doplatek a nežádoucí } \\
\text { účinky, a to v jednoduchém dávkovacím schématu s využitím fixních } \\
\text { kombinací. }\end{array}$ \\
\hline $\begin{array}{l}\text { - Řešením, které nabízí zkrácení doby v nemoci, a tedy i zachování } \\
\text { pracovní schopnosti a kvality života, je včasné zahájení preventivní } \\
\text { KV léčby se současnou kompenzací všech rizikových faktorů. I malá } \\
\text { příznivá změna, která působí dostatečně dlouho, znamená velké } \\
\text { snížení KV rizika. }\end{array}$ \\
\hline
\end{tabular}

Dnes již mezinárodní doporučení nezahrnují měření tlouštky intima/ media karotických tepen. Přesto ultrasonografie karotid, která ukáže prítomnost aterosklerotických plátů nebo zesílení tloušťky intima/ media nad 1 mm, svědčí pro strukturální změnu stěny tepen. Těmto změnám předchází endoteliální dysfunkce. I ta je klinicky měřitelná. Jde o pletysmografické měření průtokem mediované vazodilatace, jejiž opoždění nebo oslabení může svědčit o poškození cév. Vyšetření je ale časově a metodologicky náročné a v běžné praxi se nevyužívá.

\section{Měli bychom řešit hladinu LDL cholesterolu u mladšlho pacienta?}

U pacienta z modelové kazuistiky můžeme také velmi dobře využít sní̌ení hladiny LDL-C v primární KV prevenci. Řada studií prokázala, že intenzivní hypolipidemická léčba může vést nejen ke zpomalení progrese aterosklerózy, ale dokonce $k$ její regresi $(8,9)$. Podle studií REVERSAL, CAMELOT, ASTEROOD a ACZIVATE je možné dosáhnout snížení objemu aterosklerotických plátů při snížení hladiny LDL-C $<1,7$ mmol/I (9). To je hodnota, která je u pacienta z naší kazuistiky dosažitelná nejspíše pouhým podáváním statinu v monoterapii. Regrese aterosklerózy koronárních tepen je pritom proces, který významně snižuje riziko úmrtí.
Je známo, že nepříznivý vliv KV rizikových faktorů se vzájemně nesčítá, ale násobí. Proto i kompenzací více KV rizikových faktorů dosáhneme násobného prínosu. Je doloženo, že dlouhodobé snižení hladiny LDL-C o 10 \% a STK o 10 \% vede během 10 let ke snížení KV rizika o 45 \% (10). Dlouhodobého príznivého vlivu Ize dosáhnout časnou kompenzací všech KV rizikových faktorů. U našeho modelového pacienta tedy včas zahájenou souběžnou léčbou hypertenze a dyslipidemie.

\section{Jak reaguje pacient na doporučenou preventivní léčbu?}

Pacientovi z naší kazuistiky určitě doporučíme zvýšení pohybové aktivity, zanechání kouření a léčbu hypertenze a dyslipidemie. Pacient slíbí, že prestane kouřit a zredukuje tělesnou hmotnost, ale farmakoterapii zatím odmítá.

Na další kontrolu přichází po 7 letech ve věku 45 let. Stále je asymptomatický, ovšem nadále denně kouři 20 cigaret, konzumuje 2-3 piva a nevěnuje se žádné pohybové aktivitě. Jeho BMI dosáhl hodnoty 36 kg/m², TK 184/100 mm Hg, LDL-C 3,7 mmol/l, kyselina močová $680 \mu \mathrm{mol} / \mathrm{l}$ a GGT 3,1 $\mu \mathrm{kat} / \mathrm{l}$.

U takovýchto pacientů, se kterými se v praxi běžně setkáváme, dochází jednoznačně k cévním změnám. Kromě již zmíněné endoteliální dysfunkce a ztluštění vrstvy intima/media se rozvijí tuhnutí stěny tepen, které lze dobře prokázat vyšetřením rychlosti šiření pulzní vIny (PWV). Jde o diagnostickou metodu zařazenou do mezinárodních doporučení pro léčbu hypertenze. Tato metoda přináší důležitou informaci o funkční změně cév ještě před rozvojem morfologické obliterujíci léze. Vysoké hodnoty ukazují zvýšenou tuhost cév, i když naměřená hodnota je ovlivněna výší krevního tlaku. Studie zahrnující přes 16000 pacientů ukázala, že zvýšení PWV o 1 SD je spojeno s významným zvýšením rizika KV onemocnění, které je vyšší v mladším věku - konkrétně u pacientů do 50 let o 83 \% (11). Vyšetření PWV je v běžné klinické praxi jistě dostupnější než hodnocení endoteliální dysfunkce, i když standardizace zatím není jednoznačná.

Zvýšená tuhost cév odpovídá časnému stárnutí tepen označovanému dnes jako EVA (early vascular ageing). Opakem je tzv. SUPERNOVA, tj. stav, kdy cévy stárnou pomaleji, než je průměr. Nůžky křivek tuhosti cév při EVA, při prưměrné rychlosti stárnutí tepen a při SUPERNOVĚ se rozevírají již od dětského věku. Na snižení tuhosti tepen cílí léčba hypertenze. Podávání antihypertenziv je spojeno s významným poklesem PWV, přičemž nejvýraznějši efekt byl prokázán u ACEI (12). S tuhostí tepen úzce souvisí centrální aortální tlak. Studie CAFE (podstudie ASCOT) ukázala, že při dvojkombinaci antihypertenziv atenolol + thiazidové diuretikum je dosaženo stejného snižení TK měřeného na paži jako při podávání dvoj-

Obr. 2. Snižení KV rizika prì celoživotně nízké hodnotě STK anebo hladině LDL-C (3)

\begin{tabular}{|l|c|c|c|c|c|}
\hline & $\begin{array}{c}\text { Počet } \\
\text { účastníků }\end{array}$ & $\begin{array}{c}\text { Počet } \\
\text { příhod }\end{array}$ & $\begin{array}{c}\text { Rozdíl } \\
\mathbf{v} \text { LDL-C } \\
\mathbf{( m g / d l )}\end{array}$ & $\begin{array}{c}\text { Rozdíl } \\
\mathbf{v} \text { STK } \\
\mathbf{( m m ~ H g )}\end{array}$ & $\begin{array}{c}\text { Poměr šancí } \\
\mathbf{( 9 5} \% \mathbf{C l})\end{array}$ \\
\hline $\begin{array}{l}\text { Nižší LDL-C } \\
\text { a nižší STK }\end{array}$ & 105528 & 4832 & $-13,9$ & $-0,3$ & $0,61(0,59-0,64)$ \\
\hline Nižší LDL-C & 109027 & 5784 & $-14,7$ & $-0,1$ & $0,73(0,70-0,75)$ \\
\hline Nižší STK & 111097 & 6515 & 1,6 & $-2,9$ & $0,82(0,80-0,85)$ \\
\hline $\begin{array}{l}\text { Vyšší LDL-C } \\
\text { i STK }\end{array}$ & 113300 & 7849 & & & \\
\hline
\end{tabular}

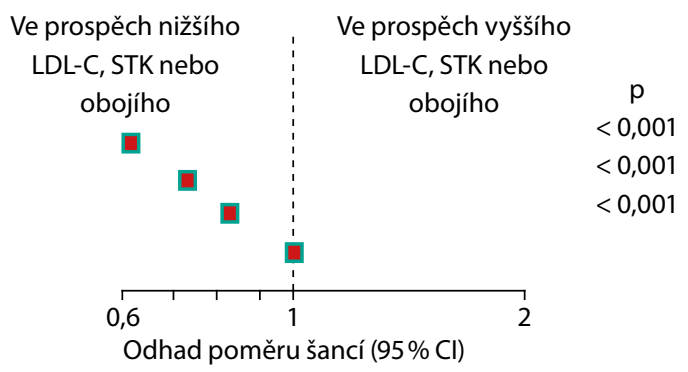


Obr. 3. Demografický profil pacientů hospitalizovaných v ČR pro akutní IM v roce 2017 (dle NRHZS rok 2017)

Pohlaví a věková struktura pacientů

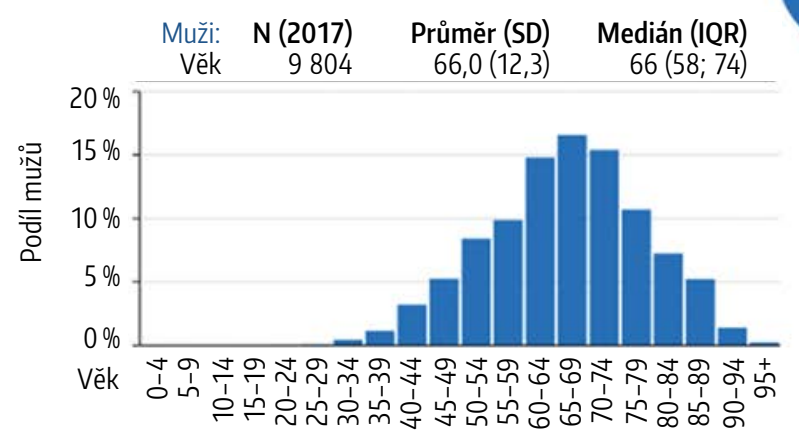

$65,3 \%$

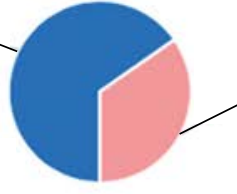

Muži $34,7 \%$
Ženy

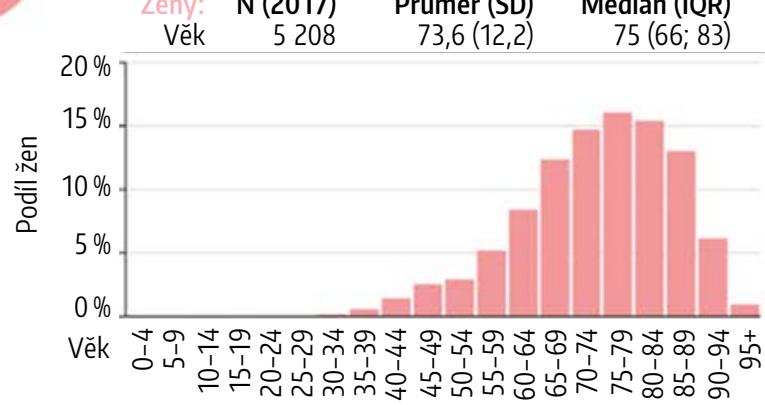

kombinace amlodipin + perindopril, ovšem pokles centrálního aortálního tlaku je významně větší při léčbě BKK + ACEl (13). Rovněž metaanalýza studií se statiny ukázala jejich významný príznivý vliv na snížení PWV (14).

Farmakologická intervence je u pacienta z naší kazuistiky určitě na místě. Ultrasonografické vyšetření karotických tepen u něj potvrdilo prítomnost aterosklerózy a vysoká hodnota PWV (karoticko-femorální PWV > $10 \mathrm{~m} / \mathrm{s}$ ) svědčí pro mnohočetné postižení tepenného řečiště.

\section{Lze ovlivnit hypertenzí zprostředkované poškození orgánů?}

Léčba antihypertenzivy dokáže určitě minimálně stabilizovat aterosklerotické postižení. Perindopril ve studii PRERSPECTIVE (podstudie EUROPA) dosáhl regrese nekalcifikovaných koronárních plátů v porovnání s placebem, což může být dáno nejen poklesem krevního tlaku, ale zřejmě i pleiotropními účinky tohoto ACEl (15).

Echokardiografie pacienta z naší kazuistiky ukázala hypertrofii levé komory (LVMi $65 \mathrm{~g} / \mathrm{m}^{2}$ ), dilataci levé síně a ejekční frakci $67 \%$. Pomocí antihypertenzní farmakoterapie je rovněž možné dosáhnout regrese hypertrofie levé komory. Metaanalýza 72 studií zahrnujících 2925 nemocných se srovnatelným snížením TK ukázala, že inhibice systému renin-angiotenzin-aldosteron (RAAS), ale také vazodilatace navozená blokátory kalciových kanálů (BKK), vede v porovnání s $\beta$-blokátory (BB) k významnému snížení LVMi (16).

Hypertenzí zprostředkované poškození orgánů (HMOD) zahrnuje u asymptomatických pacientů zvýšení tepenné tuhosti, hypertrofii levé komory, ale také poškození funkce ledvin (mikroalbuminurie, pokles eGFR) a retinopatii.

Podle platných doporučení (17) je třeba farmakologicky inned zasáhnout prì hodnotě krevního tlaku >160/110 mm Hg. Cílem je kompenzace TK do 3 měsíců. U pacientů s TK 140-159/90-99 mm Hg je doporučeno zahájit farmakoterapii v prípadě vysokého KV rizika a prítomnosti HMOD.

\section{Jak se staví pacient $\mathbf{k}$ doporučené léčbě?}

U vysoce rizikového 45letého pacienta z naší modelové kazuistiky, který má vysoký BMI, kouří, pravidelně konzumuje alkohol, má hyper- tenzi, hypercholesterolemii, metabolický syndrom, prokázanou zvýšenou tuhost cév, hypertrofii levé komory a aterosklerózu karotických tepen, je zcela jistě indikována léčba hypertenze, léčba dyslipidemie, intervence zaměřená na zanechání kouření a na zvýšení pohybové aktivity. Adherence pacientů k preventivní KV léčbě bývá ale velmi nízká. Náš pacient opět slíbil, že prestane kouřit a že zhubne, nechal si předepsat ACEI a BKK, užívání statinu ale odmítl (protože se dočetl o jejich jedovatosti).

Kouření se mu podařilo omezit, ale po 6 měsících se nedostavil pro obnovení preskripce antihypertenziv. V následujících letech se u něj objevil dnavý záchvat a byl mu predepsán allopurinol.

Na další kontrolu se dostavil po 7 letech, ve věku 52 let po angioplastice pro akutní koronární syndrom. Pacient již měl dušnost třídy NYHA II-III. Pohybové aktivitě se stále nevěnoval a jeho BMI stouplo na $38 \mathrm{~kg} / \mathrm{m}^{2}$. Přestal kourìt a pít alkohol a užíval antihypertenziva a allopurinol. TK měl 146/65 mm Hg, LDL-C 3,8 mmol/l, hladinu kyseliny močové

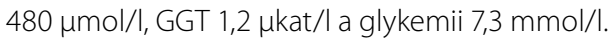

Jedná se tedy již o pacienta v sekundární KV prevenci. Takto časný IM není vzácná príhoda. Podle českých dat z roku 2017 prodělá 50 \% pacientů s IM první príhodu před 65. rokem a rovněž u velké části žen dojde k IM ještě v produktivní věku (Obr. 3). To je důvodem, proč česká populace tráví 15-20 let svého života v nemoci, se sníženou kvalitou života. I když mortalita na KV choroby klesá, ICHS je stále hlavní př̌činou smrti české populace.

\section{Jak snižit mortalitu pacientů v sekundární KV prevenci?}

Po IM dochází v lidském organismu ke kompenzačním mechanismům, jako je vyplavení kmenových buněk z kostní dřeně. Ty se ukládají na místech poškození tepen v celé cirkulaci, kde mají silné prozánětlivé účinky a mohou vést $k$ destabilizaci ateromových plátů (18). Pacienti po IM s aterosklerotickým onemocněním postihujícím i další tepny (karotické, tepny dolních končetin) nejsou ohroženi jen dalším IM, ale také CMP a ischemickou chorobou dolních končetin (ICHDK) (19). 
Obr. 4. Non-adherentnípacient s časně a dlouhodobě zvýšeným KV rizikem
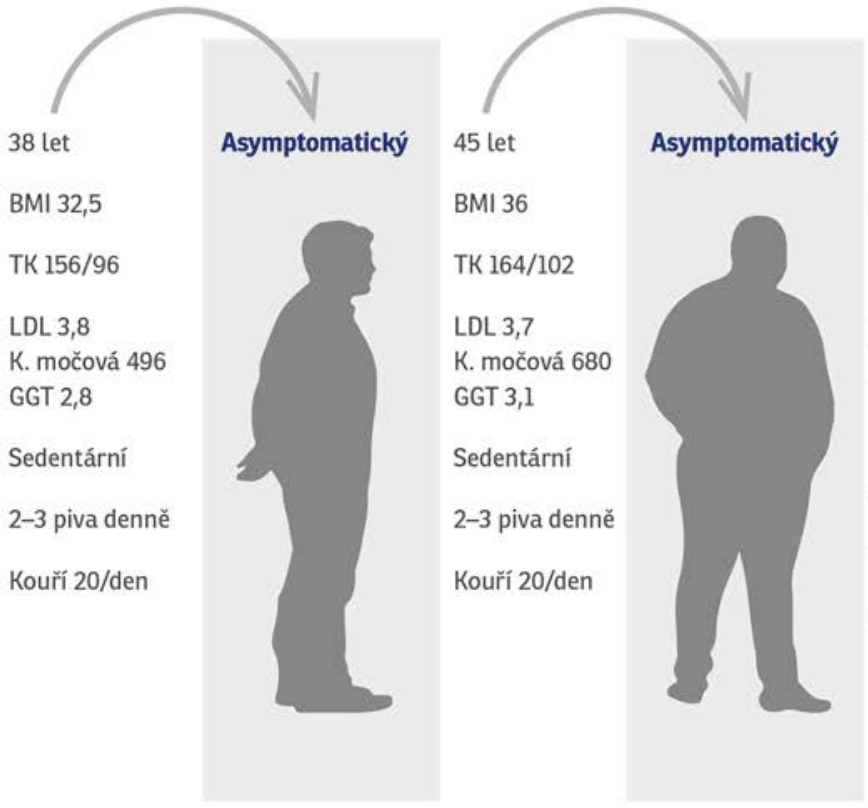

Pacient po IM bude mít jistě předepsanou duální protidestičkovou léčbu, ACEI, statin a podle ejekční frakce také BB. Jde o nemocného, který je kromě dalších aterosklerotických príhod ohrožen rozvojem srdečního selhání a poruchami rytmu. Jeho komplexní léčba znamená nemalou zátěž pro zdravotní systém i jeho rozpočet. U pacienta z naší kazuistiky byla po úspěšné akutní léčbě IM echokardiograficky prokázána porucha kinetiky srdeční stěny inferolaterálně.

Řada léků s príznivým vlivem na odvrácení remodelace myokardu prokázala také snížení mortality. Patří mezi ně i perindopril, který u pacientů po nedávno prodělaném IM se zachovanou ejekční frakcí (> 40 \%) během 1 roku léčby ve studii PREAMI významně snízil celkovou mortalitu a odvrátil remodelaci myokardu (12). Prokázán byl také jeho synergický účinek s BB, kdy kombinace perindopril + BB v porovnání s perindoprilem + placebem významně snížila výskyt složeného sledovaného parametru zahrnujícího celkovou mortalitu, KV mortalitu, hospitalizace pro srdeční selhání a výskyt fatálního i nefatálního IM (21).

\section{Proč jsou doporučeny tak nízké cílové hladiny LDL cholesterolu?}

Intenzita snižování hladiny LDL-C vychází z KV rizika. U nízkého KV rizika je doporučená hodnota $<3$ mmol/l. Dưležité je nezapomínat na potřebu snižování LDL cholesterolu již u mladších pacientů se středním KV rizikem (SCORE $\geq 1$ a $<5 \%$ ), kde je cílová hodnota podle aktuálních doporučení <2,6 mmol// (22). A samozřejmě pacienti s vysokým (SCORE $\geq 5$ a $<10 \%$ ) a s velmi vysokým KV rizikem (SCORE $\geq 10 \%$ ), kam spadají všichni nemocní v sekundární prevenci, nesmějí odcházet z ambulance bez agresivní hypolipidemické léčby. Cílové hodnoty LDL-C jsou u nich < 1,8 mmol/l, resp. < 1,4 mmol/l a snížení hladiny nejméně o $50 \%$. Pro pacienty s aterosklerotickým KV onemocněním a s druhou KV príhodou v průběhu 2 let při současném užívání

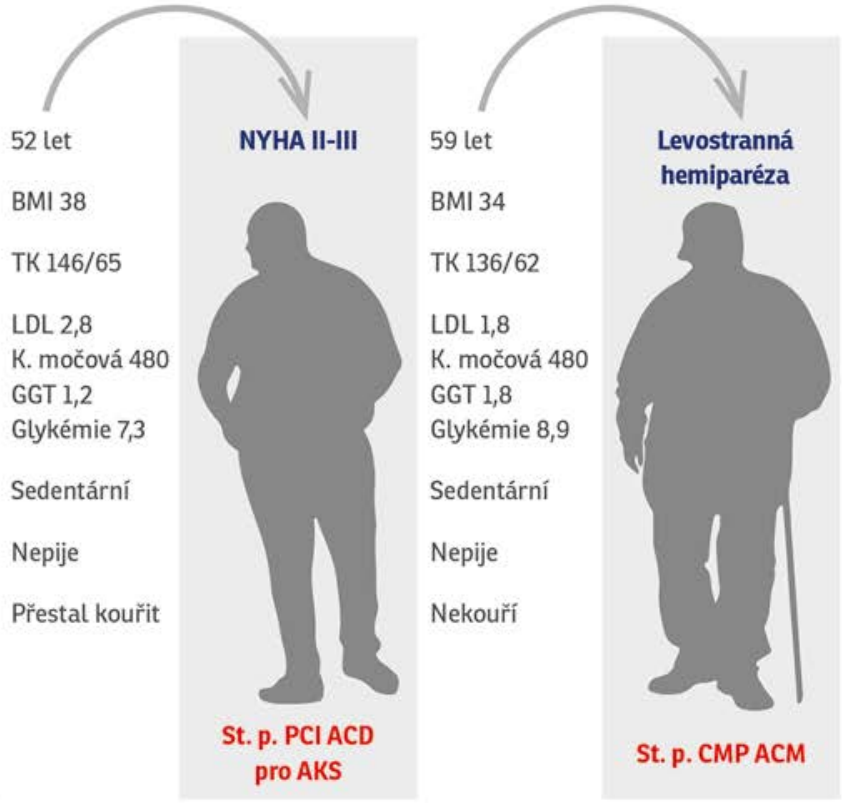

maximální tolerované dávky statinu a ezetimibu je doporučená cílová hladina LDL-C < 1,0 mmol/l. Moderní hypolipidemická léčba takové cílové hodnoty umožňuje a dosud nebyl zjištěn žádný nepříznivý dopad takto nízkých hladin LDL-C.

Podle posledních poznatků je ale mnohem výhodnější začít méně agresivní hypolipidemickou léčbou již v nižším věku u pacientů se středním KV rizikem, u nichž lze využít dlouhodobého příznivého působení nízkých hladin LDL-C.

\section{Jak zvýšit adherenci pacientů $\mathbf{k}$ léčbě}

Bohužel většina pacientů v sekundární KV prevenci nedosahuje cílových hodnot TK ani LDL-C. Podle dat z registru EUROASPIRE V z let 2016-2017 (23) nedosáhne 71 \% pacientů léčených pro hypertenzi nebo dyslipidemii TK < 130/80 a LDL-C < 1,8 mmol/l.

Pacient z naší kazuistiky tak může dospět v 59 letech do stavu nejen po IM, ale i po CMP s levostrannou hemiparézou, ztrátou pracovní schopnosti a výrazným snížením kvality života ještě v produktivním věku (Obr. 4). Nevyužití možnosti časné a dlouhodobé kompenzace KV rizikových faktorů tak u mnoha pacientů vede k nepríznivým výsledkům i prí pozdějším dosažení cílových hodnot TK a LDL-C a zvyšuje počet let života strávených v nemoci.

Studie, která hodnotila adherenci k léčbě statinů podle poklesu hladiny LDL-C (24), ukázala největší snížení KV rizika u pacientů s agresivní hypolipidemickou terapií, ovšem adherence k předepsané střední nebo nízké dávce statinů snížila KV riziko více než předepsaná vysoká dávka při non-adherenci. V ambulanci je možné vytipovat pacienty se zvýšeným rizikem non-adherence a upravit strategii léčby tak, aby se toto riziko minimalizovalo. Rizikové faktory non-adherence zahrnují:

- velice mladý věk či vysoký věk,

- aktivní kouření, 
- vysokotučnou stravu,

- nedostatek pohybu,

- nově nasazený lék,

- nového pacienta,

- žádnou dalšíléčbu,

- príliš mnoho dalších léků,

- nežádoucí účinky léku,

- finanční náklady,

- mediální zprávy negativního vyznění o dané terapii.

Především takovýmto pacientům by měl lékař vždy vysvětlit, co chceme podáváním léku docílit, a srozumitelnou formou mu sdělit, proč je třeba začít s farmakoterapií a úpravou životní stylu nyní a ne až později. Léky by měly být vhodně zvoleny s ohledem na lékové interakce, doplatek a prípadné nežádoucí účinky. Nutná je proto znalost interakcí a nežádoucích účinků a jejich vysvětlení pacientovi. Velkým prínosem z hlediska adherence je zjednodušení způsobu užívání léků, zejména co nejnižší počet užívaných tablet a co nejjednodušší schéma užívání. V tom mohou pomoci nové formy léků a fixní kombinace účinných látek v jedné tabletě.

\section{LITERATURA}

1. GBD 2017 Disease and Injury Incidence and Prevalence Collaborators. Global, regional, and national incidence, prevalence, and years lived with disability for 354 diseases and injuries for 195 countries and territories, 1990-2017: a systematic analysis for the Global Burden of Disease Study 2017. Lancet. 2018 Nov 10; 3 92(10159): 1789-1858.

2. Ettehad D, Emdin CA, Kiran A et al. Blood pressure lowering for prevention of cardiovascular disease and death: a systematic review and meta-analysis. Lancet. 2016 Mar 5 387(10022): 957-967.

3. Ference BA, Bhatt DL, Catapano AL et al. Association of Genetic Variants Related to Combined Exposure to Lower Low-Density Lipoproteins and Lower Systolic Blood Pressure With Lifetime Risk of Cardiovascular Disease. JAMA. 2019 Oct 8; 322(14): 1381-1391. 4. Böhm M, Schumacher $H$, Teo KK et al. Achieved blood pressure and cardiovascular outcomes in high-risk patients: results from ONTARGET and TRANSCEND trials. Lancet. 2017 Jun 3; 389(10085): 2226-2237.

5. Rawshani A, Rawshani A, Franzén et al. Risk Factors, Mortality, and Cardiovascular Outcomes in Patients with Type 2 Diabetes. N Engl J Med. 2018; 379(7): 633-644.

6. Yusuf S, Joseph P, Rangarajan S et al. Modifiable risk factors, cardiovascular disease, and mortality in 155722 individuals from 21 high-income, middle-income, and low-income countries (PURE): a prospective cohort study. Lancet. 2020 Mar 7; 395(10226): 795-808.

7. Tuzcu EM, Kapadia SR, Tutar E et al. High prevalence of coronary atherosclerosis in asymptomatic teenagers and young adults: evidence from intravascular ultrasound. Circulation. 2001; 103(22): 2705-2710.

8. Ahmadi A, Narula J. Primary and Secondary Prevention, or Subclinical and Clinical Atherosclerosis. JACC Cardiovasc Imaging. 2017 Apr;10(4):447-450.

9. Nicholls SJ, Tuzcu EM, Sipahi I et al. Statins, high-density lipoprotein cholesterol, and regression of coronary atherosclerosis. JAMA. 2007 Feb 7;297(5):499-508.

10. Emberson J, Whincup P, Morris R et al. Evaluating the impact of population and high-risk strategies for the primary prevention of cardiovascular disease. Eur Heart J. 2004 Mar; 25(6): 484-491.

11. Ben-Shlomo Y, Spears M, Boustred C et al. Aortic pulse wave velocity improves cardiovascular event prediction: an individual participant meta-analysis of prospective observational data from 17,635 subjects. J Am Coll Cardiol. 2014 Feb 25; 63(7): 636-646.

12. Ong KT, Delerme S, Pannier B et al. investigators. Aortic stiffness is reduced beyond blood pressure lowering by short-term and long-term antihypertensive treatment: a meta-analysis of individual data in 294 patients. J Hypertens. 2011 Jun; 29(6): 1034-1042.

13. Williams B, Lacy PS, Thom SM et al. CAFE Investigators; Anglo-Scandinavian Cardiac Outcomes Trial Investigators; CAFE Steering Committee and Writing Committee. Differential impact of blood pressure-lowering drugs on central aortic pressure and clinical

\section{Závĕr}

Máme k dispozici řadu prostředků, pomocí nichž jsme schopni snižit KV riziko pacientů, pokud je budeme využívat. V nejbližší době nás v důsledku opatření během pandemie covidu-19 pravděpodobně čeká „pandemie" zvýšení KV rizika z dưvodu zanedbání primární i sekundární prevence. Úkolem lékařů bude přesvědčit pacienty o prínosu preventivní KV léčby a zvolit farmakoterapii v jednoduchém dávkovacím schématu s minimálním počtem predepsaných tablet. K edukaci pacienta Ize využít i výsledky některých vyšetřovacích metod, jako je ultrasonografie karotických tepen znázorňující aterosklerotické pláty nebo vyšetření tuhosti tepen. V rámci edukace Ize využít také cévní věk, kdy informace o stáŕi vlastních cév, které značně převyšuje jeho kalendářní věk, může být pro pacienta motivací k dodržování terapeutických opatření. Pacienty je třeba presvědčit, že zodpovědnost za své zdraví mají ve vlastních rukou a že je třeba snažit se o zdravější životní styl a dodržování preventivní farmakoterapie. Změny mohou být relativně malé, pokud se uplatní včas, protože pak Ize těžit z jejich dlouhodobého přiznivého působení. I včas nasazená jednoduchá farmakoterapie hypertenze a dyslipidemie vede dlouhodobě k zachování cévního zdraví. Pripravila MUDr. Zuzana Zafarová

outcomes: principal results of the Conduit Artery Function Evaluation (CAFE) study. Circulation. 2006 Mar 7; 113(9): 1213-1225.

14. Upala S, Wirunsawanya K, Jaruvongvanich V, Sanguankeo A. Effects of statin therapy on arterial stiffness: A systematic review and meta-analysis of randomized controlled trial. Int J Cardiol. 2017 Jan 15; 227: 338-341.

15. Bruining N, de Winter S, Roelandt JR et al. EUROPA/PERSPECTIVE Investigators. Coronary calcium significantly affects quantitative analysis of coronary ultrasound: importance for atherosclerosis progression/regression studies. Coron Artery Dis. 2009 Sep; 20(6): 409-414. 16. Klingbeil AU, Schneider M, Martus P et al. A meta-analysis of the effects of treatment on left ventricular mass in essential hypertension. Am J Med. 2003 Jul; 115(1): 41-46.

17. Williams B, Mancia G, Spiering W, et al; ESC Scientific Document Group. 2018 ESC/ESH Guidelines for the management of arterial hypertension. Eur Heart J. 2018 Sep 1; 39(33): 3021-3104.

18. Dutta P, Courties $G$, Wei $Y$ et al. Myocardial infarction accelerates atherosclerosis. Nature. 2012 Jul 19; 487(7407): 325-329.

19. Gutierrez JA, Aday AW, Patel MR, Jones WS. Polyvascular Disease: Reappraisal of the Current Clinical Landscape. Circ Cardiovasc Interv. 2019 Dec; 12(12): e007385.

20. Ferrari R. Perindopril and Remodeling in Elderly with Acute Myocardial Infarction Investigators. Effects of angiotensin-converting enzyme inhibition with perindopril on left ventricular remodeling and clinical outcome: results of the randomized Perindopril and Remodeling in Elderly with Acute Myocardial Infarction (PREAMI) Study. Arch Intern Med. 2006 Mar 27; 166(6): 659-666.

21. Bertrand ME, Ferrari R, Remme WJ et al. Perindopril and $\beta$-blocker for the prevention of cardiac events and mortality in stable coronary artery disease patients: A EUropean trial on Reduction Of cardiac events with Perindopril in stable coronary Artery disease (EUROPA) subanalysis. Am Heart J. 2015 Dec; 170(6): 1092-1098.

22. Mach F, Baigent C, Catapano AL et al. ESC Scientific Document Group. 2019 ESC/EAS Guidelines for the management of dyslipidaemias: lipid modification to reduce cardiovascular risk. Eur Heart J. 2020 Jan 1; 41(1): 111-188.

23. Kotseva K, De Backer G, De Bacquer D et al. EUROASPIRE Investigators*. Lifestyle and impact on cardiovascular risk factor control in coronary patients across 27 countries: Results from the European Society of Cardiology ESC-EORP EUROASPIRE V registry. Eur J Prev Cardiol. 2019 May; 26(8): 824-835.

24. Khunti K, Danese MD, Kutikova L et al. Association of a Combined Measure of Adherence and Treatment Intensity With Cardiovascular Outcomes in Patients With Atherosclerosis or Other Cardiovascular Risk Factors Treated With Statins and/or Ezetimibe. JAMA Netw Open. 2018 Dec 7; 1(8): e185554. 